\title{
Gradual Strengthening of Existing Masonry Houses with Ferrocement Bandaging
}

\author{
Febrin Anas Ismail ${ }^{1}$, Teddy Boen ${ }^{2}$, Rendy Thamrin ${ }^{1 *}$ \\ ${ }^{1}$ Department of Civil Engineering, Faculty of Engineering, Andalas University, \\ Padang, 25163, West Sumatera, Indonesia \\ ${ }^{2}$ CSI Indonesia, Raya Pejuangan, Kebon Jeruk, Jakarta 11530, Indonesia \\ *Corresponding Author: rendythamrin@eng.unand.ac.id
}

\begin{abstract}
Approximately 85 million people's houses are scattered all over Indonesia, and almost all are in strong earthquake areas. In every earthquake, the houses are generally damaged or collapsed. Therefore, those houses must be strengthened to make them earthquake resistant. This paper discusses a gradual strengthening of existing houses using ferrocement bandaging. The gradual strengthening is introduced due to limited funding of the people. It also serves as an educational tool to educate people to be self-sufficient in building their earthquake-resistant houses. The first step, maybe the sleeping room shall be strengthened so that if there is an earthquake during night-time, people will be safe, and if there is an earthquake during the daytime, people can immediately run to that particular room. A global analysis is made of a sample house shaken by Palu, Central Sulawesi earthquake 2018, and West Sumatra earthquake 2009, with one room strengthened to show that the strengthened room can survive the earthquakes. Then the analysis is continued gradually to the other rooms until the masonry house is fully strengthened by ferrocement bandaging. The results show that the masonry house strengthened by ferrocement layers is earthquake resistant.
\end{abstract}

Keywords: gradual strengthening, existing masonry houses, earthquake disaster, ferrocement bandaging 


\section{Introduction}

On average, every two years, there is a strong earthquake in Indonesia, and every time most of the people's houses are damaged or collapse, causing the loss of property and human life. From past earthquakes, it is evident that the damage and or collapse of people's houses were caused by the unavailability of standard building materials and poor quality. Among others, poor quality mortar, poor quality mix, and poor-quality detailing of reinforcing bars $[1,2,3]$. The majority of the existing houses are poor quality (see Figure. 1 to Figure. 4). The most sensible measure to take is strengthening all current people's houses using an economical and straightforward method that local masons can use. So far, people's houses damaged by earthquakes are dependent on government funding to repair their buildings. Therefore, people must be educated to be self-reliant and self-supporting in building earthquake-resistant houses [4,5,6,7]. People should be encouraged to be independent and not dependent on the government. However, the government should provide technical assistance. Technical assistance must be carried out comprehensively at all levels of society to increase understanding of earthquake disasters. The steps must be taken to be independent in building earthquake-resistant houses to prevent casualties in the future. A multi-sectoral approach is needed to make a vulnerability reduction program effective. Training must be action-oriented, and demand-driven and should focus on vulnerability reduction $[5,6,7,8,8,10,11]$.

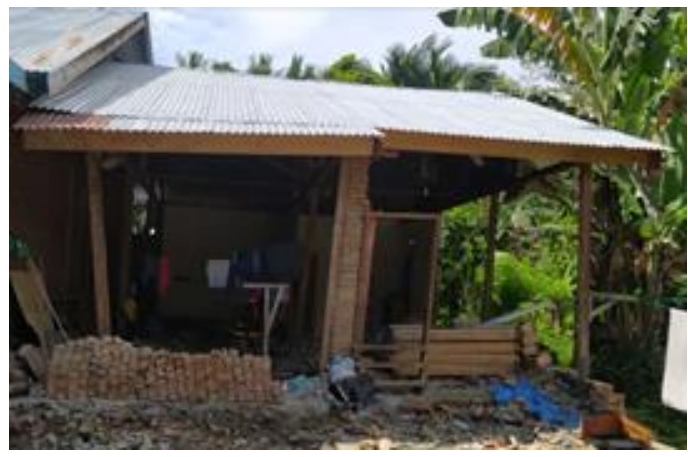

(a)

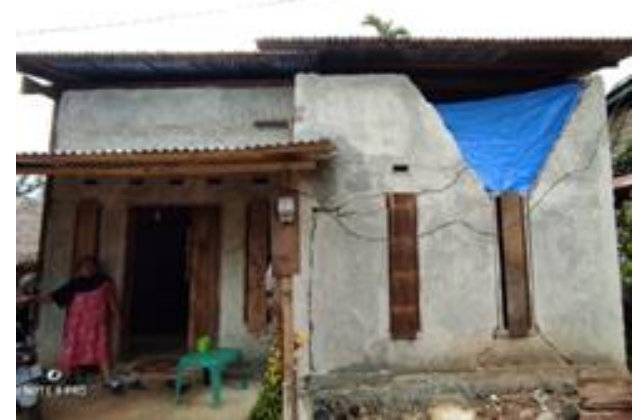

(c)

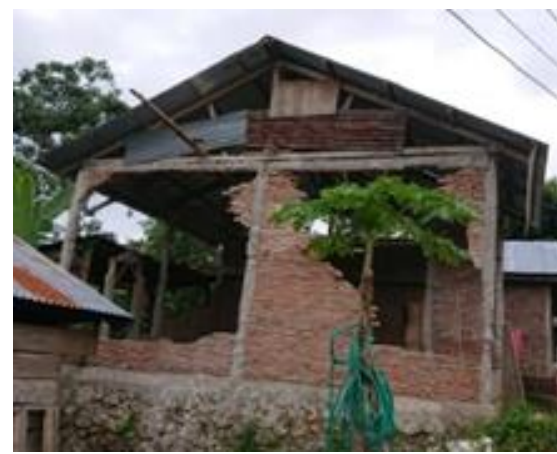

(b)

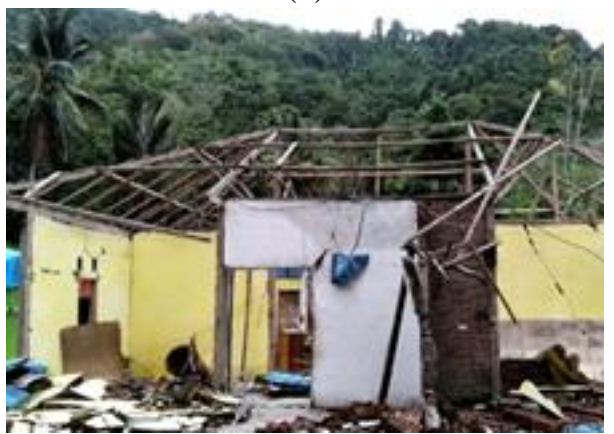

(d)

Figure 1. Examples of poorly built houses from the West Sulawesi Earthquake on January 15th, 2021 


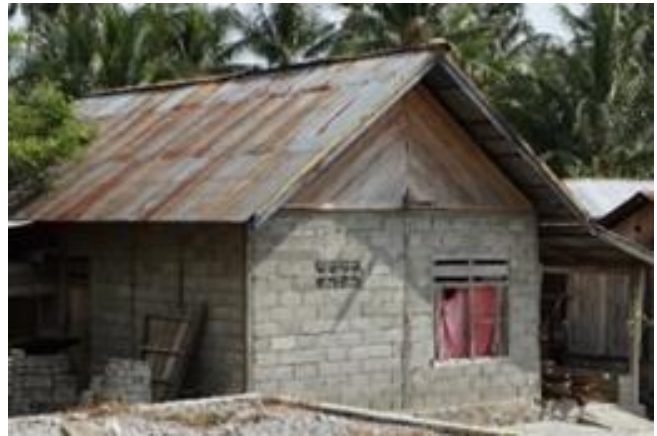

(a)

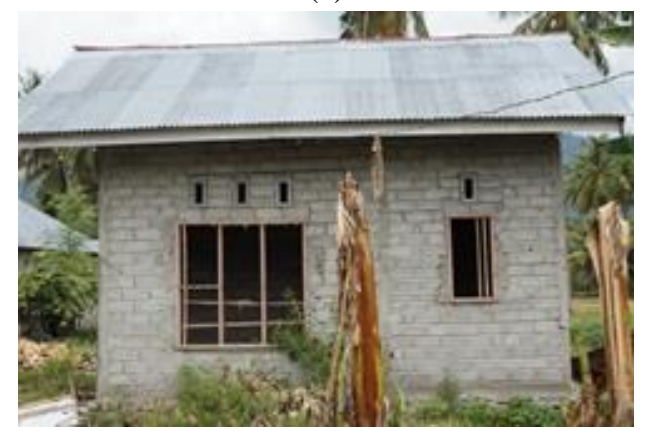

(c)

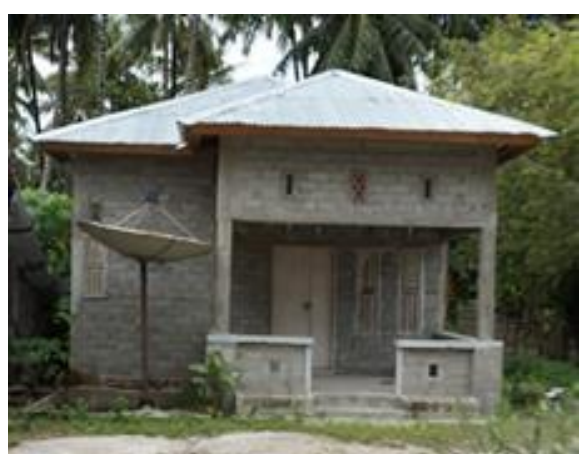

(b)

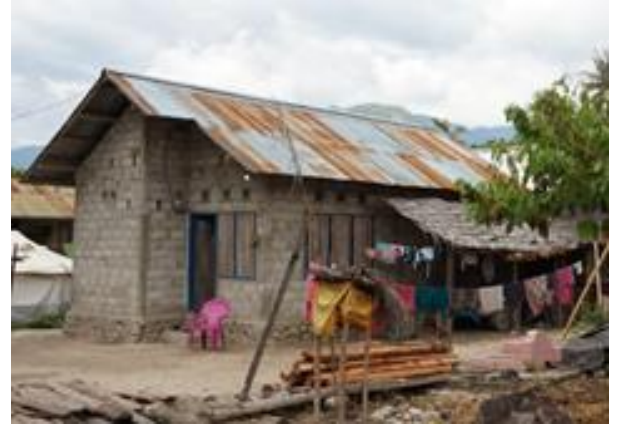

(d)

Figure 2. Examples of poorly built houses from the Palu (Central Sulawesi) Earthquake on September 28th, 2018

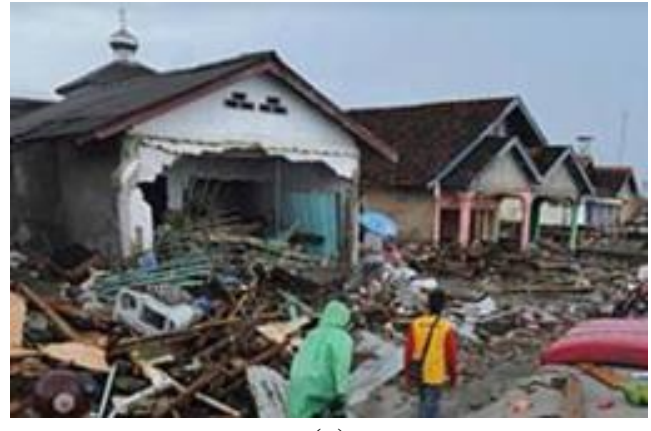

(a)

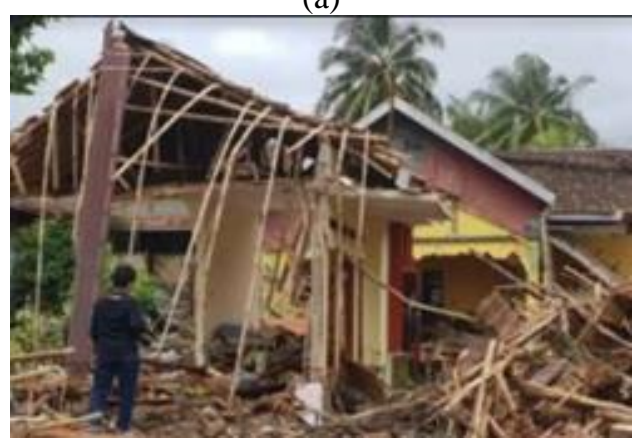

(c)

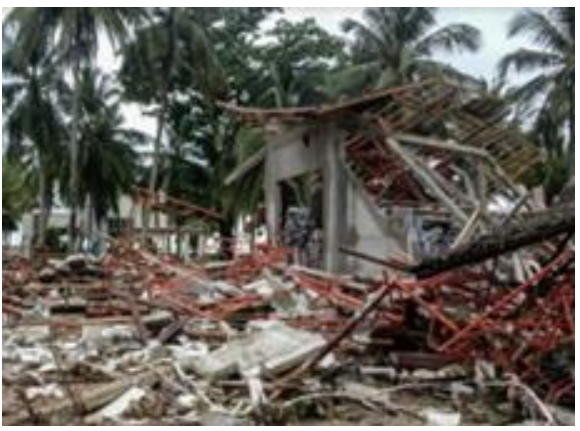

(b)

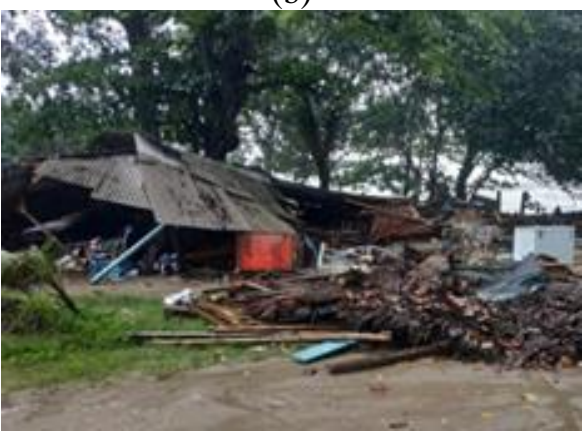

(d)

Figure 3. Examples of poorly built houses from the Selat Sunda Earthquake and Tsunami on December 22th, 2018 


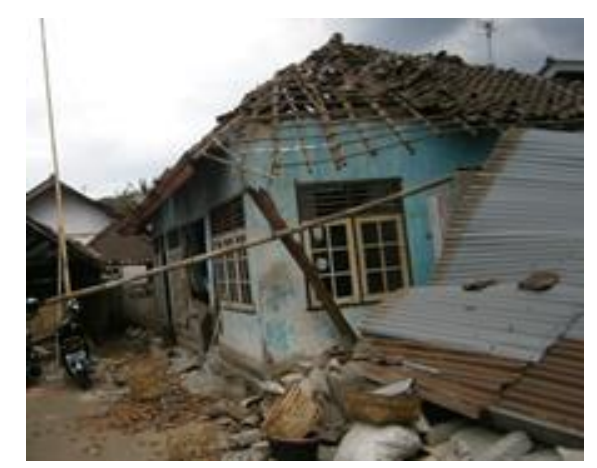

(a)

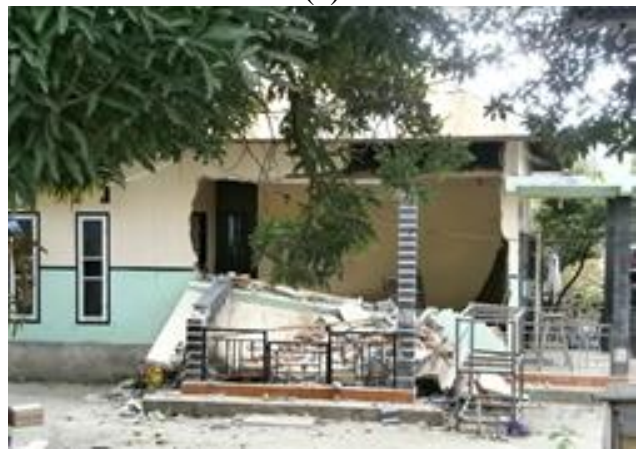

(c)

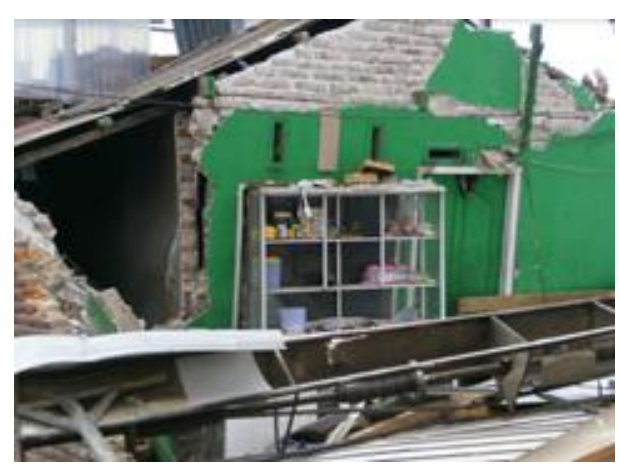

(b)

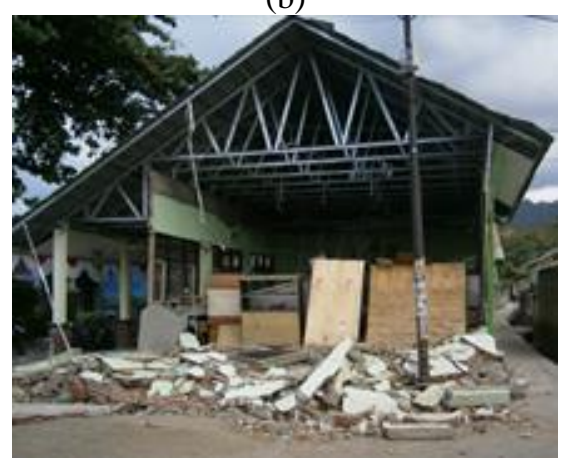

(d)

Figure 4. Examples of poorly built houses from the Lombok Earthquake on July 29th, 2018

Reconstruction of masonry houses after the earthquake so far has not been running well. Many permanent houses promised by the government were not fulfilled, and even 3-4 years after the disaster, the problem became unclear. With self-reliance and self-supporting, assisted by NGOs with proven reputations and transparent accountability, people can quickly recover to build earthquake-resistant houses. Therefore, the problem becomes resolved and not protracted. [12].

Since several years ago, a strengthening method using ferrocement bandaging was introduced and already practiced in several places in Indonesia [13]. The most affordable and straightforward strengthening method is bandaging with ferrocement layers. Besides ferrocement layers, if available, Fiber Reinforced Cementitious (FRC) layers or Textile Fiber Composite (TRC) can be used [13]. The method is simple and does not need demolition or reconstruction. Because of financial problems, people are reluctant to build earthquake-resistant houses. In their opinion, it is too costly; therefore, this paper proposes gradual strengthening to make the funding of earthquake-resistant houses affordable. This is carried out by strengthening one room at a time so that in case of an earthquake that can occur any time, especially at nighttime, people can stay in that room and be safe from collapsed walls. For this purpose, the authors perform dynamic analysis of a simple masonry house with gradual strengthening starting from stage 1 (one room strengthened by ferrocement bandaging). Then strengthening is continued to stage 2 and stage 3 . Gradual 
strengthening does not mean that retrofitting can be delayed for years, but rather that reinforcement must be carried out as soon as possible to prevent collapse due to an upcoming earthquake. Three stages should be finished within one year, meaning the masonry house is fully strengthened by ferrocement bandaging (see Figure. 5).
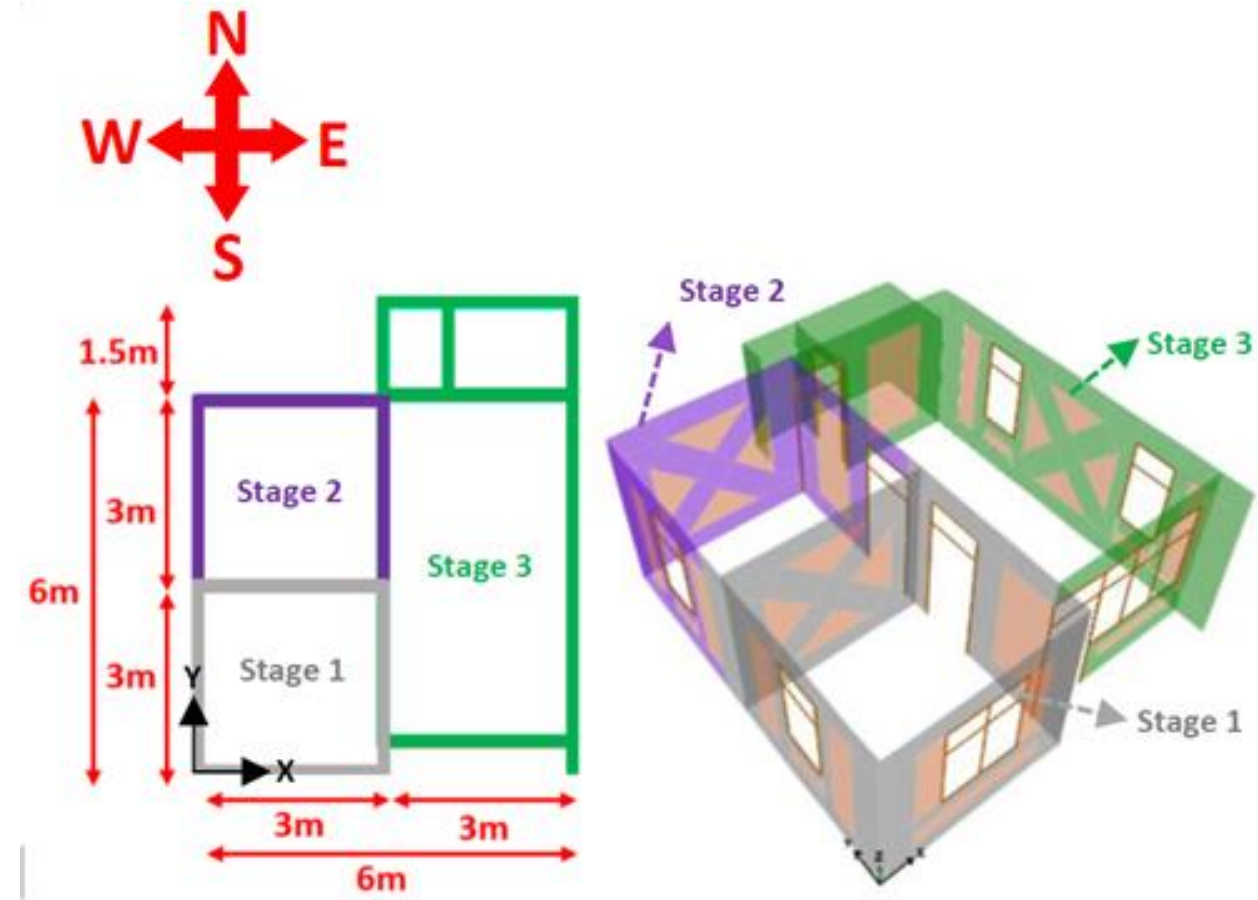

Figure 5. Sample layout of a gradual strengthening masonry house

\section{Structural Model}

The analysis model of sample house bandaged by ferrocement layers follow the same method as indicated in reference [14]. The gradual strengthening analysis is started from the first stage, one bedroom. Then it is continued to the next bedroom for the second stage and subsequently completed for the last step, which is bandaging the entire masonry house, as shown in Figure. 5.

The modeling of an existing masonry house uses columns and beams of poor quality, as is the reality found in actual practice. Columns and beams do not need to be dismantled. Just restored and directly bandaged with ferrocement layers. Figure. 6 shows the model of the sample masonry house for the analysis, and Figure. 7 depicts the installation sketch of ferrocement layers. 


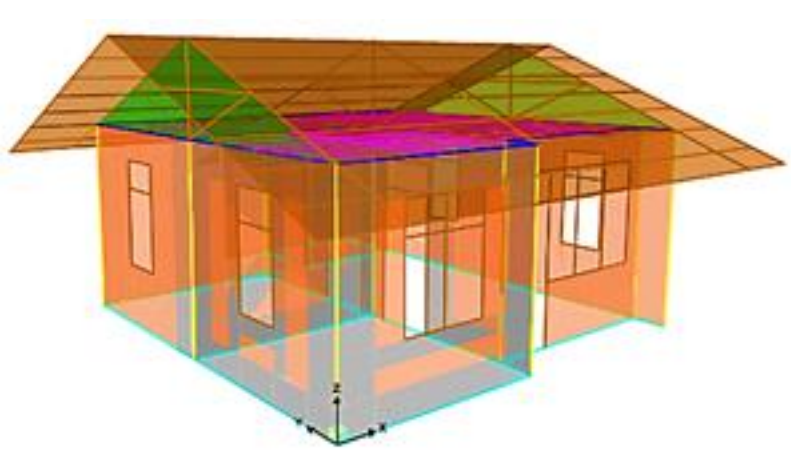

(a) 3D View

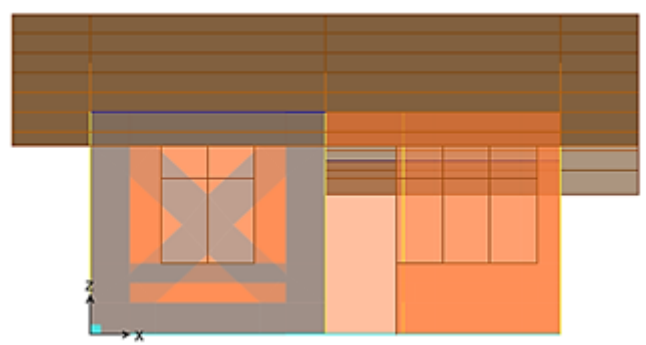

(c) Front view

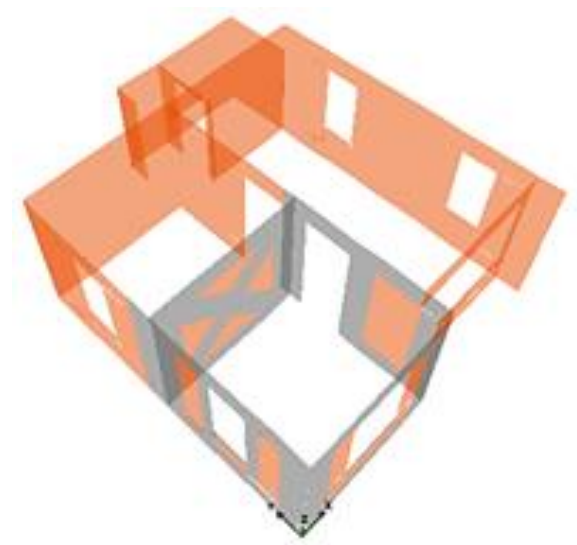

(b) One strengthened room

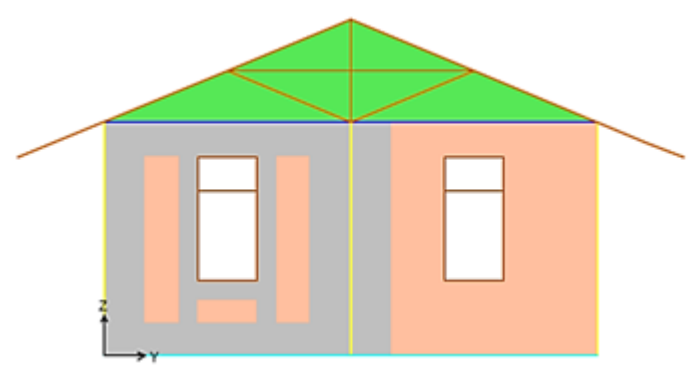

(d) Left view

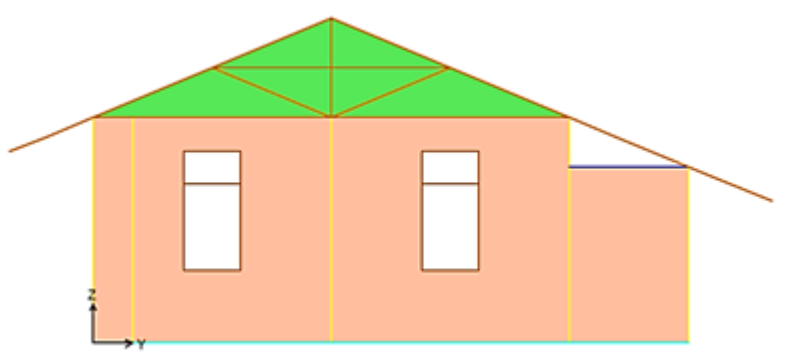

(e) Right view

Figure 6. Model of sample house with one strengthened room
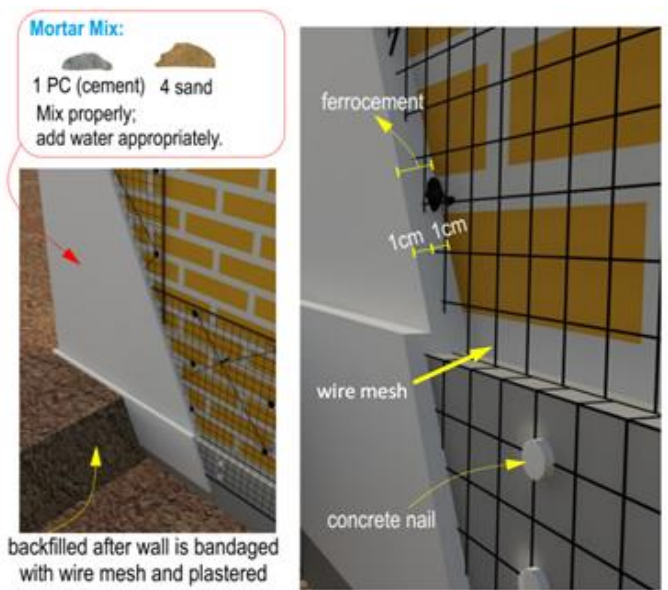

Figure 7. Sketch of ferrocement layer installation [15] 


\section{Material Properties}

Material properties of the masonry wall used for the analysis are taken from the previous shaking table test in Tsukuba, 2014 [14]. The modulus elasticity of masonry wall is $5885 \mathrm{kgf} / \mathrm{cm}^{2}\left(1 \mathrm{kgf} / \mathrm{cm}^{2}=0,098 \mathrm{MPa}\right)$ with adhesion tensile strength of mortar (1pc:6sand) used for the masonry wall is $3.5 \mathrm{kgf} / \mathrm{cm}^{2}$ as cited in the reference. The compressive strength of mortar (1 pc: 4 sand) for the ferrocement layer is $275.8 \mathrm{kgf} / \mathrm{cm}^{2}$, and the modulus elasticity is $211950 \mathrm{kgf} / \mathrm{cm}^{2}$, as mentioned in the reference. For columns and beams, the compressive strength of concrete used in the analysis is $\mathrm{K}-150\left(150 \mathrm{kgf} / \mathrm{cm}^{2}\right)$. According to the Indonesian code (SNI 7973-2013), wooden for window frames, door frames, truss, and purlins used second-grade wood has $740 \mathrm{kgf} / \mathrm{m}^{3}$ density and $112168 \mathrm{kgf} / \mathrm{cm}^{2}$ modulus of elasticity (E11) [16].

\section{Input Motion}

The earthquake records used in the analysis are the September 28th, 2018 Palu (Central Sulawesi) earthquake (0.33g) and the September 30th, 2009 Padang (West Sumatra) earthquake $(0.3 \mathrm{~g})$ [17,18]. The Palu earthquake record represents a single pulse-type earthquake dominant in the U-D direction (see Figure. 8). Meanwhile, the Padang earthquake record represents multiple pulse-type earthquakes dominant in the N-S direction (see Figure. 9). The model analysis for both earthquake records is conducted by running earthquake loads in 3 directions simultaneously, namely the $\mathrm{X}, \mathrm{Y}$, and $\mathrm{Z}$ directions of the building, as shown in Figure. 6. The X-direction of the building is given an E-W direction of earthquake load, the $\mathrm{Y}$ direction of the building is given an N-S direction of earthquake load, and the Z-direction of the building is given a U-D direction of earthquake load.

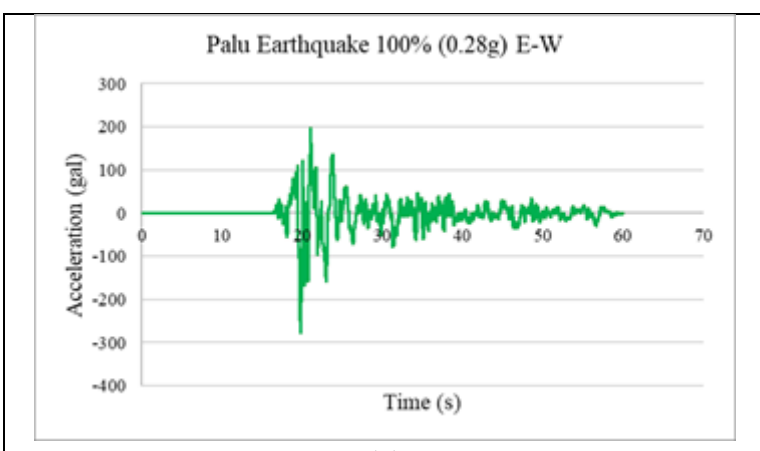

(a)

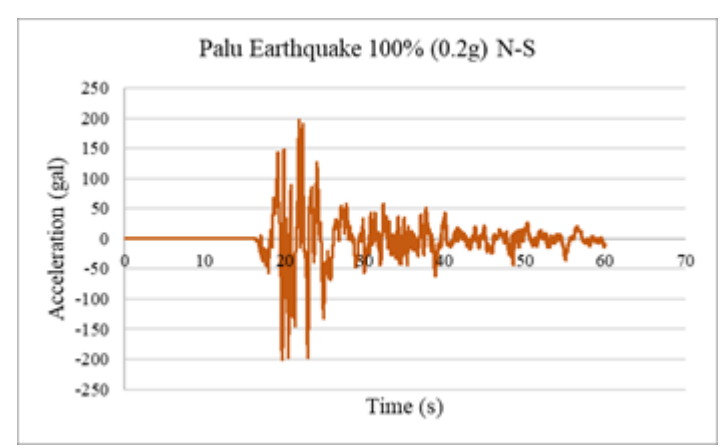

(b) 


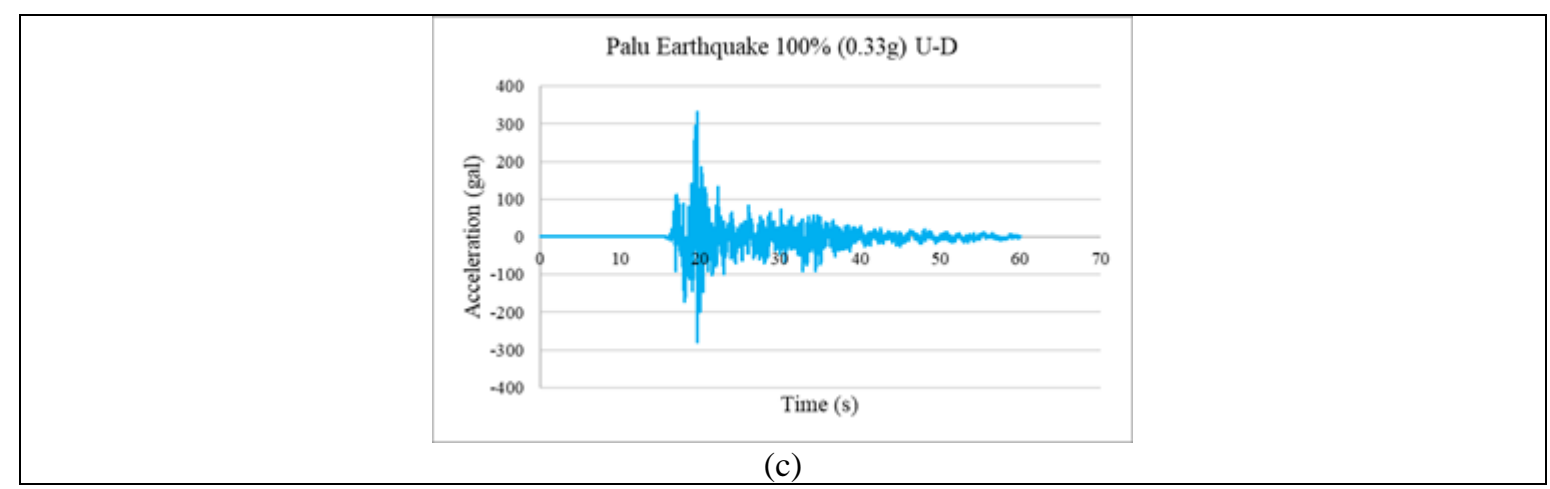

Figure 8. Palu (Central Sulawesi) earthquake records [17]

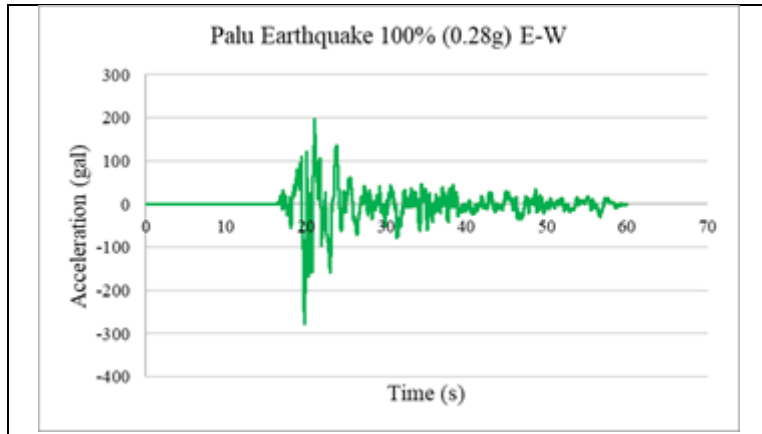

(a)

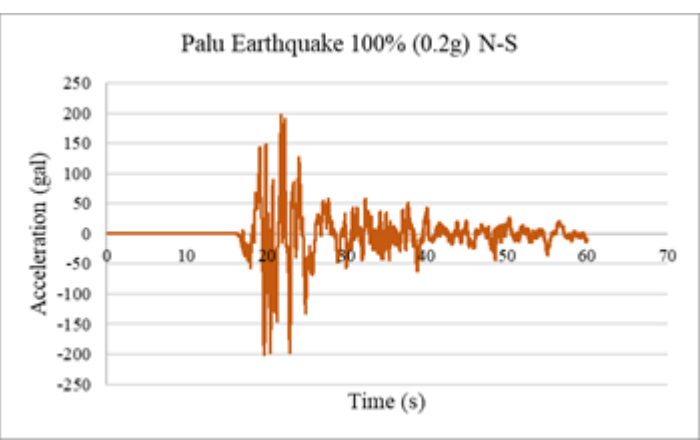

(b)

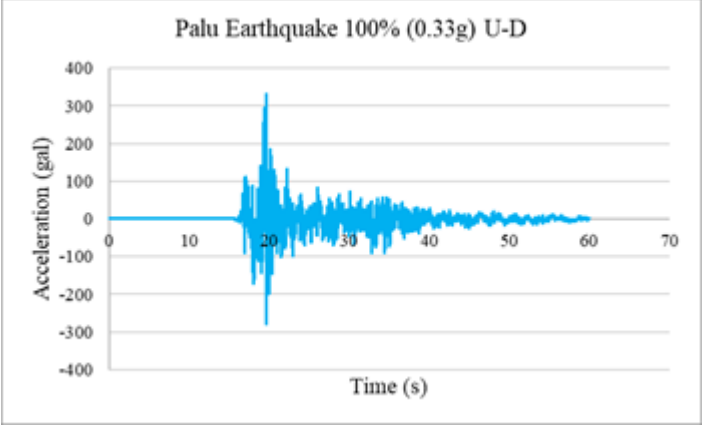

(c)

Figure 9. Padang (West Sumatra) earthquake records [18]

\section{Results and Discussion}

The results of gradual strengthening analysis started from stage 1 to stage 3 show a significant impact on the strength of masonry houses when bandaged using ferrocement layers. Below are the graphs to summarize the maximum tensile stress resulting from the Palu and Padang earthquake shaking (see Figure. 10 until Figure. 12). The result of each stage is elaborated deeply in part 5.1. until 5.4. 


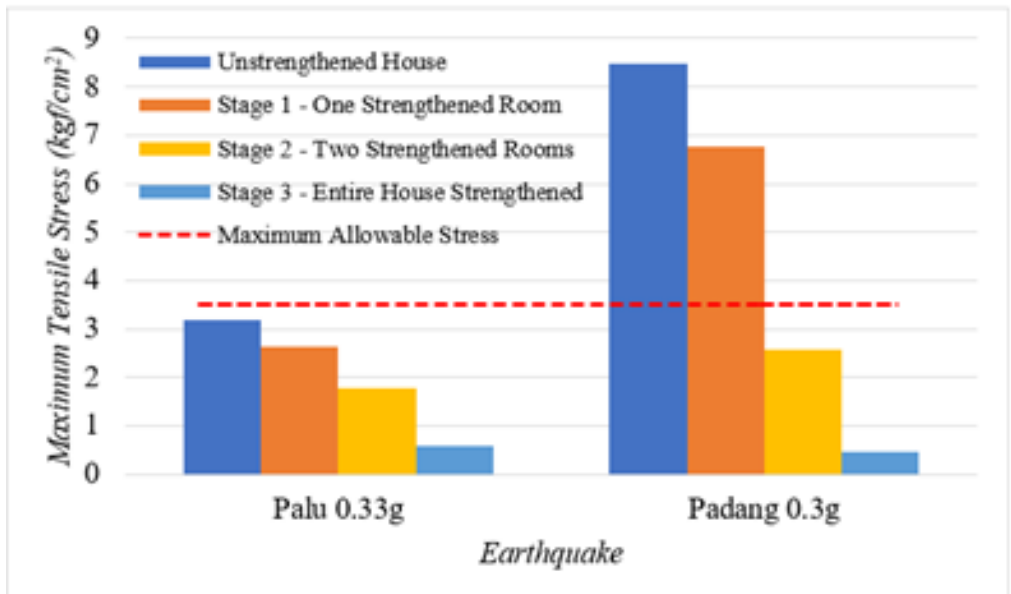

Figure 10. The maximum tensile stress of masonry wall

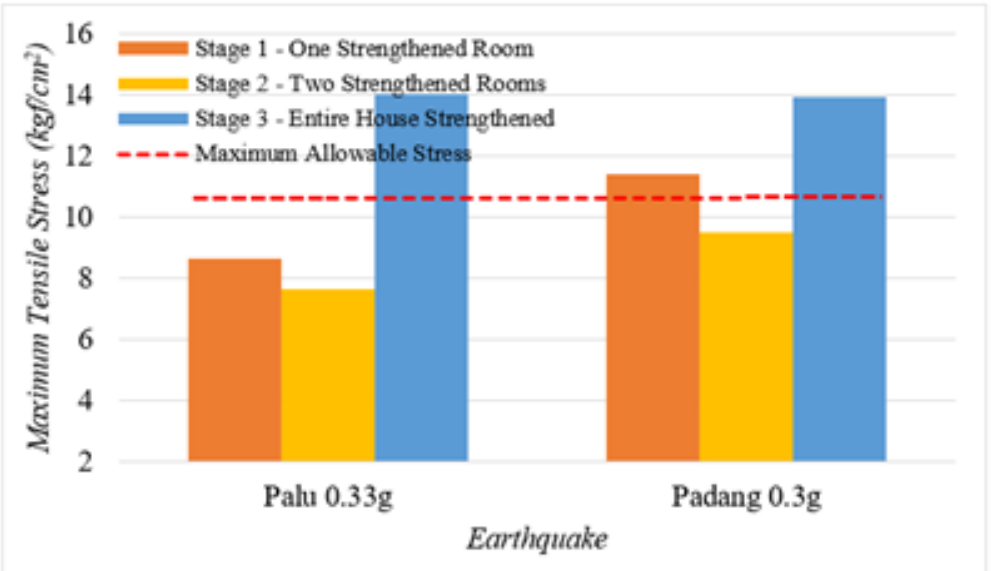

Figure 11. The maximum tensile stress of outer ferrocement layers

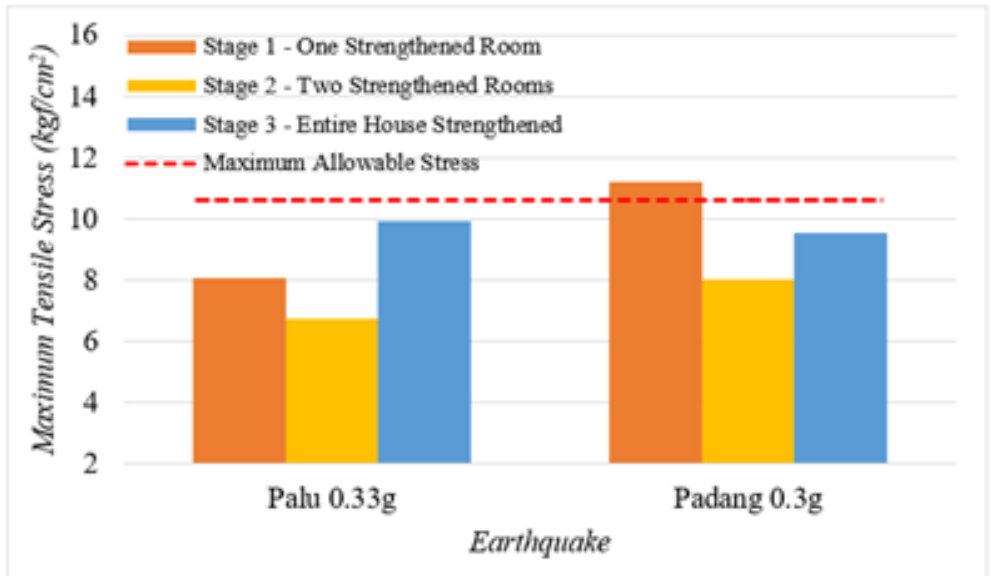

Figure 12. The maximum tensile stress of inner ferrocement layers 


\subsection{Analysis Results of Unstrengthened House}

The results of the analysis of unreinforced masonry houses when shaken by Palu and Padang earthquakes provide a significant difference due to the characteristics of the Padang earthquake, which is a multiple pulse type. In contrast, the Palu earthquake is a single pulse type. It proves that the masonry walls were quite strong when shaken by the Palu earthquake, while when they were shocked by the Padang earthquake, most of the wall tensile stress had exceeded the allowable stress limit $\left(3.5 \mathrm{kgf} / \mathrm{cm}^{2}\right)$ as indicated in blue color. As shown in Figure. 10, the tensile stress in the walls reaches $8.48 \mathrm{kgf} / \mathrm{cm}^{2}$. It could be said that the walls were heavily damaged and might even collapse.

The damaged walls indicated in blue color are the result of the high level of the out-of-plane load caused by the N-S direction earthquake. Since Padang earthquake records in the N-S direction are more significant than E-W (see Figure. 9), the damaged masonry walls in Figure. 13 are perpendicular to the N-S direction. Based on the above finding, it is suggested that the strengthening of masonry houses should be prioritized and implemented.

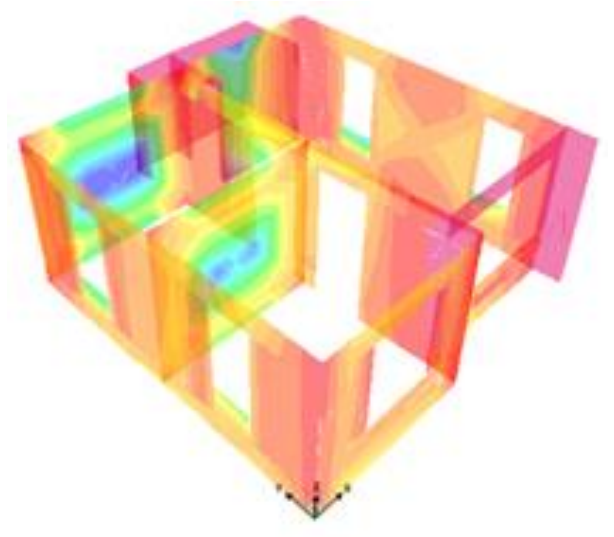

(a)

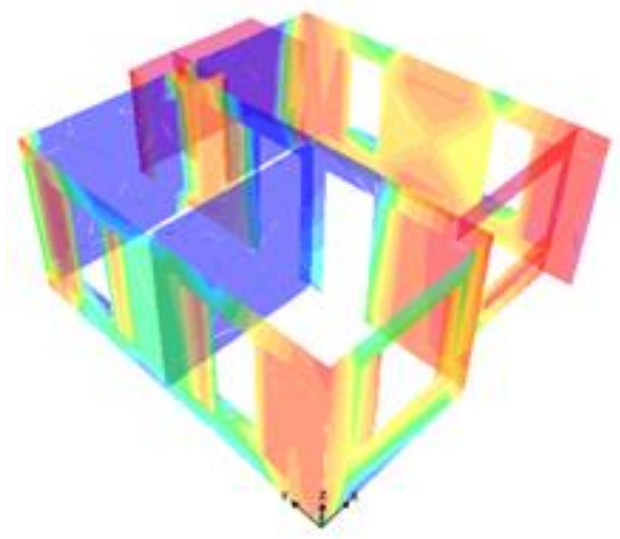

(b)

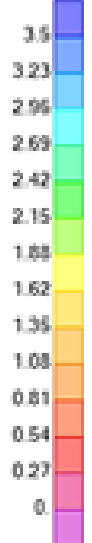

Figure 13. The maximum tensile stress pattern of masonry wall (unit in $\mathrm{kgf} / \mathrm{cm}^{2}$ ) due to (a) Palu earthquake and (b) Padang earthquake

\subsection{Analysis Results of Stage 1 - one strengthened room}

From the analysis, when shaken by the Palu earthquake, the tensile stress at a small part of the unstrengthened masonry wall (Figure. 14) exceeds the allowable stress limit $\left(3.5 \mathrm{kgf} / \mathrm{cm}^{2}\right)$, whereas, for strengthened masonry wall, the tensile stress occurred is very small. When shaken by the Padang earthquake, the unstrengthened masonry wall suffered severe damage, marked by blue color in some parts. From Figure. 10 , the maximum stress at the masonry wall is $6.77 \mathrm{kgf} / \mathrm{cm}^{2}$. 
For one room strengthened by ferrocement layers, when shaken by the Padang earthquake, the tensile stress in the ferrocement layers slightly exceeds the allowable stress (the maximum stress that occurred was 11.4 $\mathrm{kgf} / \mathrm{cm}^{2}$, as can be seen in Figure. 11 and Figure. 12). This indicates that the ferrocement layers may experience a slight crack but not collapse (see Figure. 15 and Figure. 16).

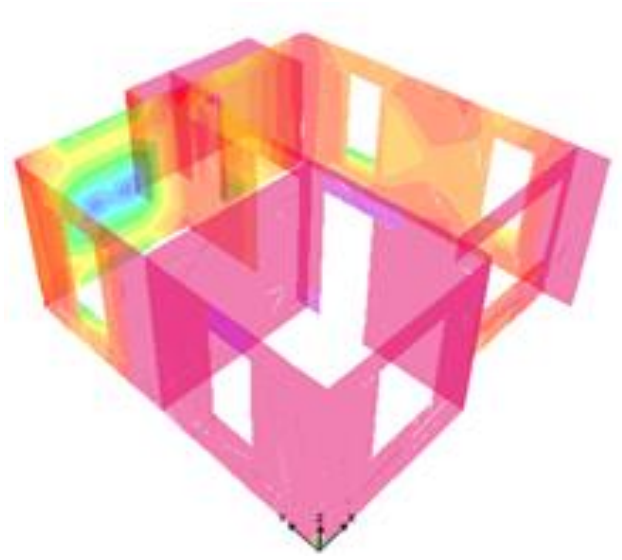

(a)

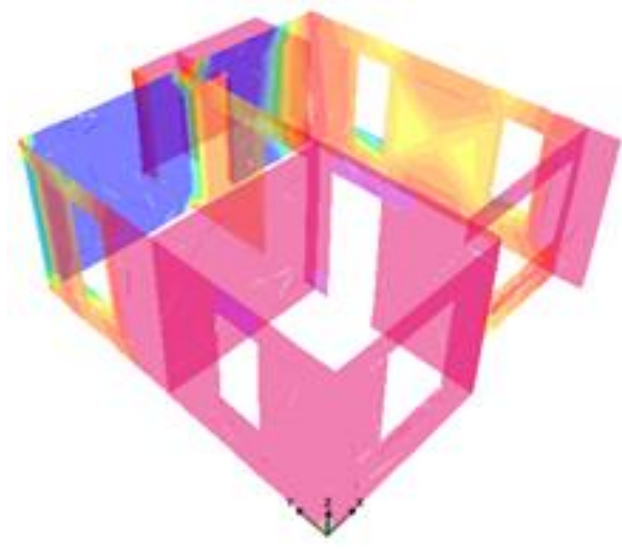

(b)

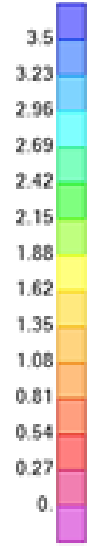

Figure 14. The maximum tensile stress pattern of masonry wall (unit in $\mathrm{kgf} / \mathrm{cm}^{2}$ ) due to (a) Palu earthquake and (b) Padang earthquake

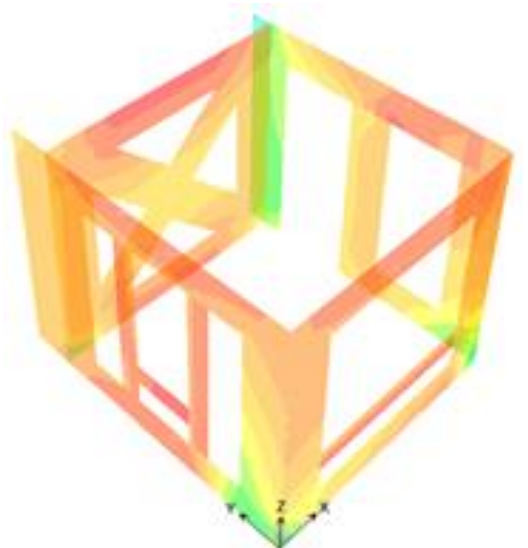

(a)

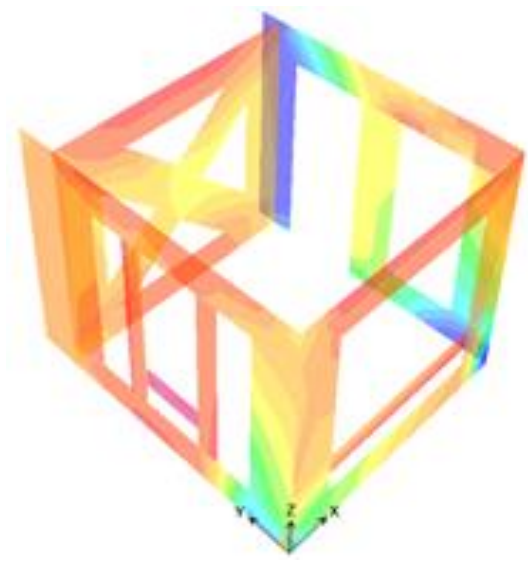

(b)

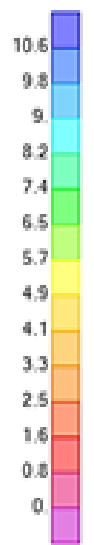

Figure 15. The maximum tensile stress pattern of outer ferrocement layers (unit in $\mathrm{kgf} / \mathrm{cm}^{2}$ ) due to (a) Palu earthquake and (b) Padang earthquake 


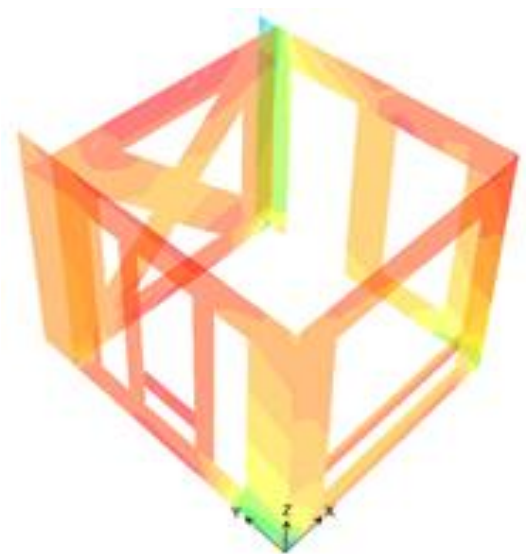

(a)

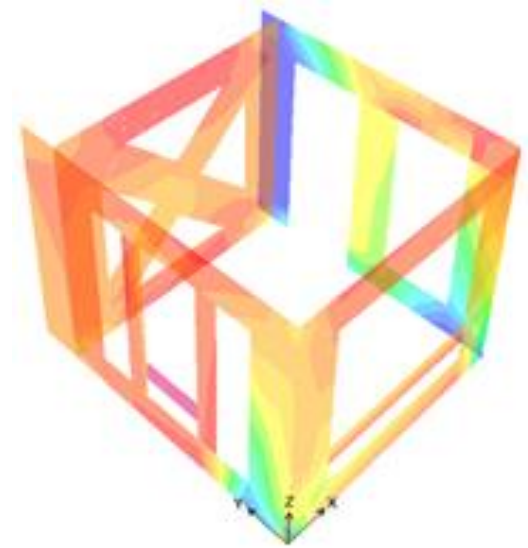

(b)

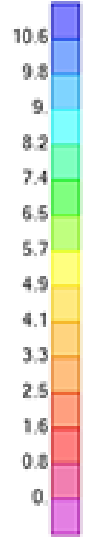

Figure 16. The maximum tensile stress pattern of inner ferrocement layers (unit in $\mathrm{kgf} / \mathrm{cm}^{2}$ ) due to (a) Palu earthquake and (b) Padang earthquake

\subsection{Analysis Results of Stage 2 - two strengthened rooms}

In the second stage, the strengthening is applied to 2 bedrooms. For the unreinforced masonry wall, the analysis results show that the maximum stress in the North wall did exceed the allowable stress limit when shaken by the Padang earthquake (see Figure. 17). This is influenced by the Padang earthquake's out-of-plane load, which is much more significant in the $\mathrm{Y}$ direction $(0.3 \mathrm{~g})$ than in the house's $\mathrm{X}$ direction $(0.25 \mathrm{~g})$.

Compared to the prior analysis of one strengthened room (see Figure. 14), the previously unstrengthened second room is now earthquake-resistant due to the ferrocement bandaging.

The earthquake can occur at any time. Therefore, it is better to strengthen the masonry house entirely up to stage 3. For both the inner and outer ferrocement layers, it can be seen clearly that the tensile stress that occurred in ferrocement layers is only around 3-6 kgf/cm ${ }^{2}$ (see Figure. 18 and Figure. 19), below the allowable tensile stress limit $\left(10.63 \mathrm{kgf} / \mathrm{cm}^{2}\right)$.

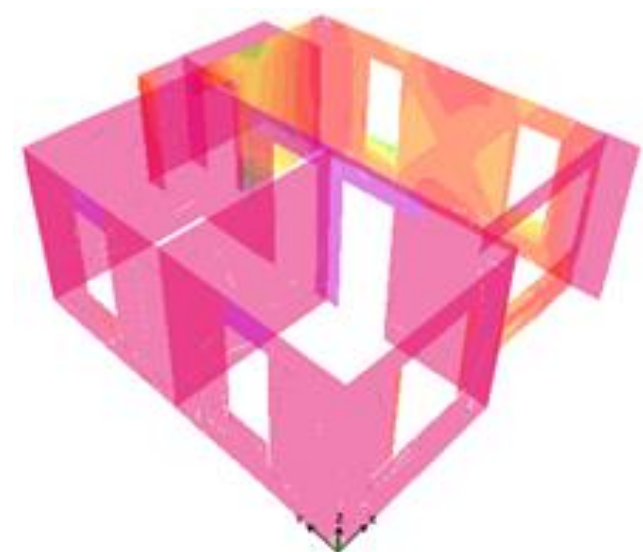

(a)

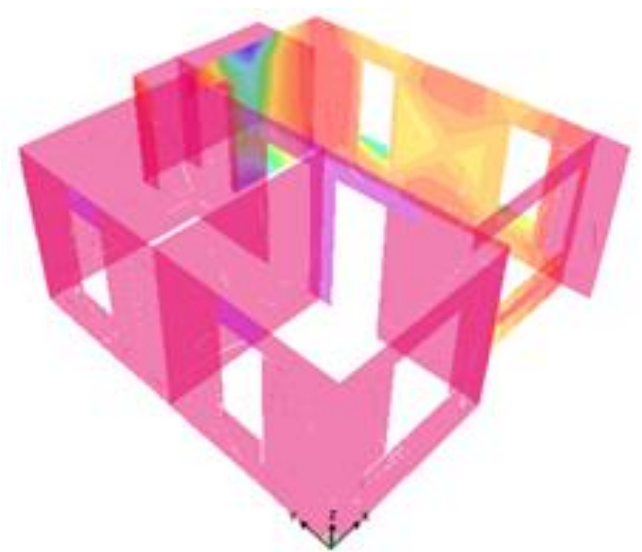

(b)

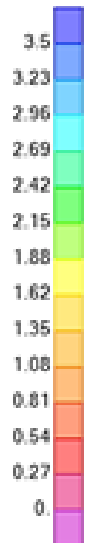

Figure 17. The maximum tensile stress pattern of masonry wall (unit in $\mathrm{kgf} / \mathrm{cm}^{2}$ ) due to (a) Palu earthquake and (b) Padang earthquake 


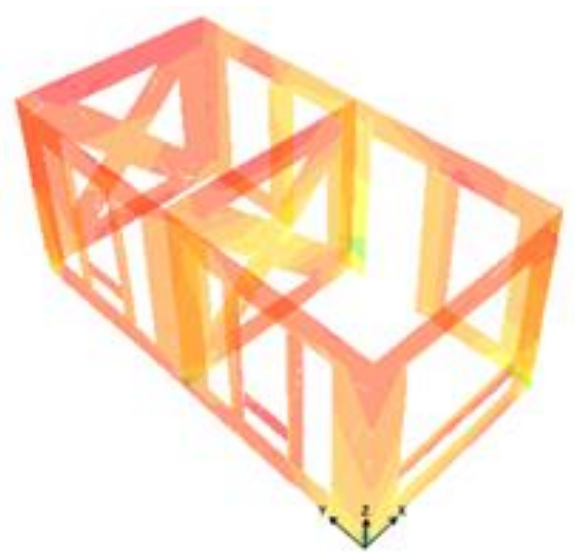

(a)

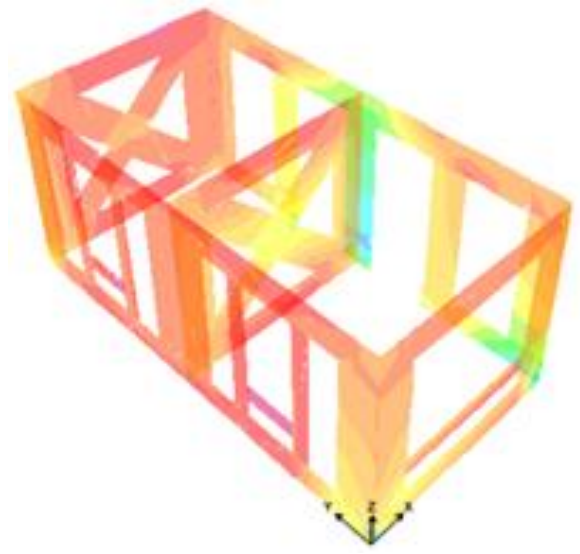

(b)

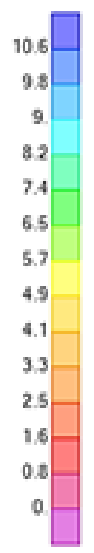

Figure 18. The maximum tensile stress pattern of outer ferrocement layers (unit in $\mathrm{kgf} / \mathrm{cm}^{2}$ ) due to (a) Palu earthquake and (b) Padang earthquake

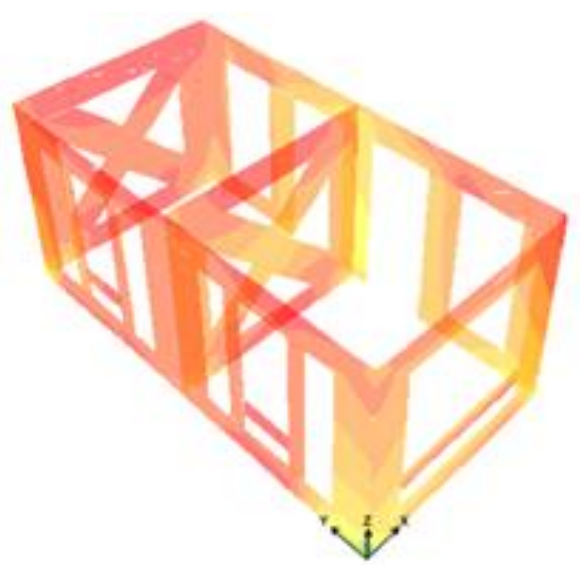

(a)

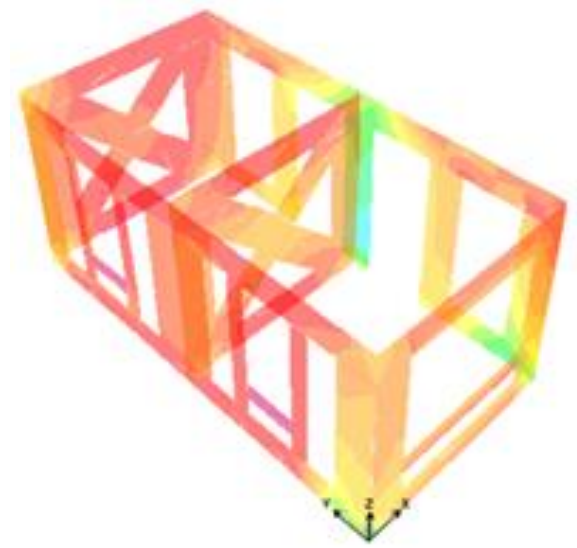

(b)

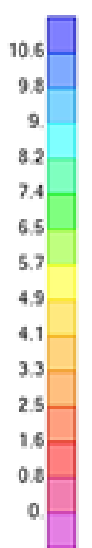

Figure 19. The maximum tensile stress pattern of inner ferrocement layers (unit in $\mathrm{kgf} / \mathrm{cm}^{2}$ ) due to (a) Palu earthquake and (b) Padang earthquake

\subsection{Analysis Results of Stage 3 - entire house strengthened}

When all masonry walls are strengthened by ferrocement bandaging, the tensile stresses are become smaller, as shown in Figure. 20. In general, the tensile stress of ferrocement layers when shaken by Palu and Padang earthquakes was below the allowable stress $(10.63 \mathrm{kgf} / \mathrm{cm} 2)$, as shown in Figure. 21 and Figure. 22. For the right wall, where there is no room partition, the tensile stress of outer ferrocement layers slightly exceeds the allowable stress (see Figure. 11), which indicates the possibility of cracks. The analysis results of stage 3 show that the masonry house strengthened by ferrocement layers is earthquake resistant. 


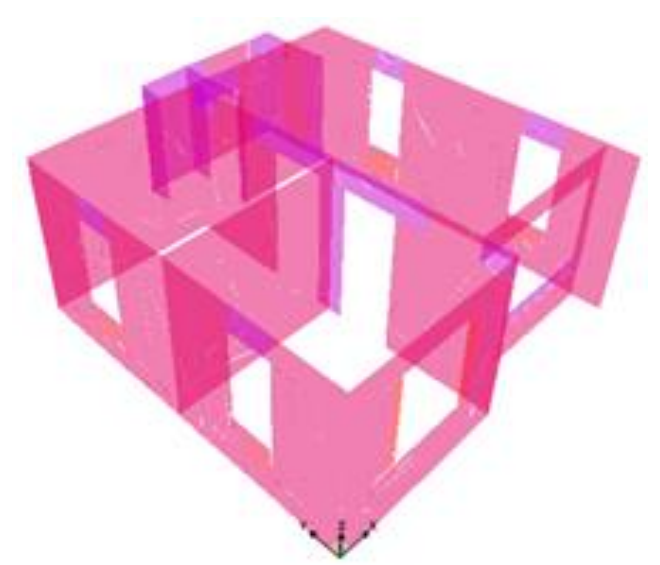

(a)

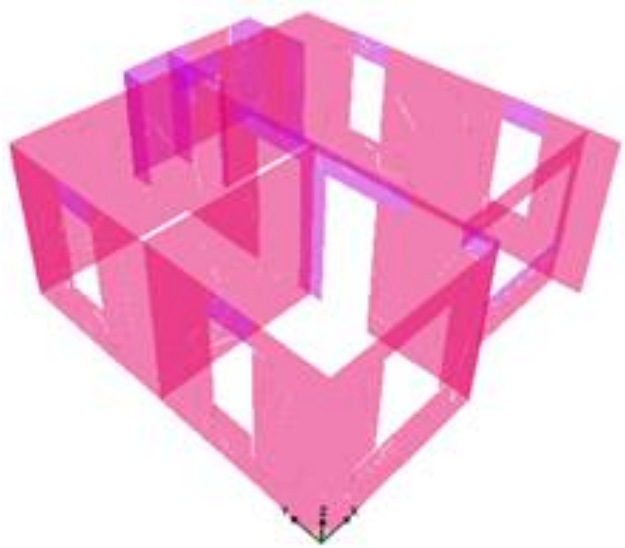

(b)

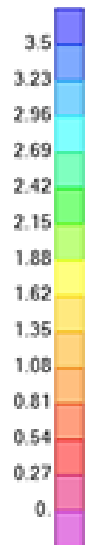

Figure 20. The maximum tensile stress pattern of masonry wall (unit in $\mathrm{kgf} / \mathrm{cm}^{2}$ ) due to (a) Palu earthquake and (b) Padang earthquake

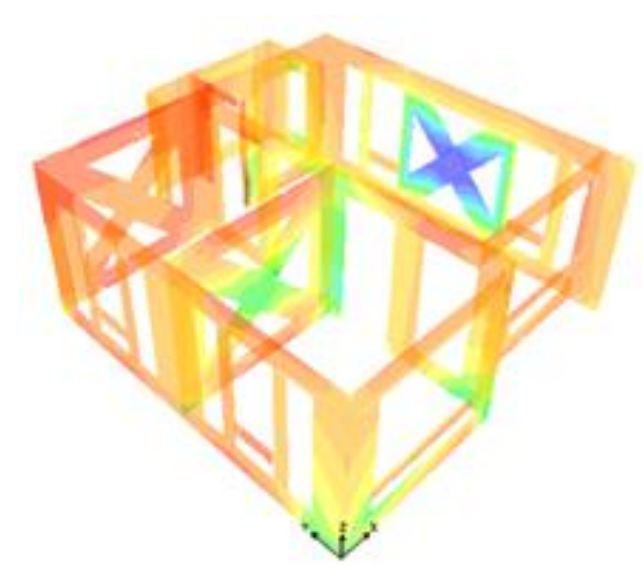

(a)

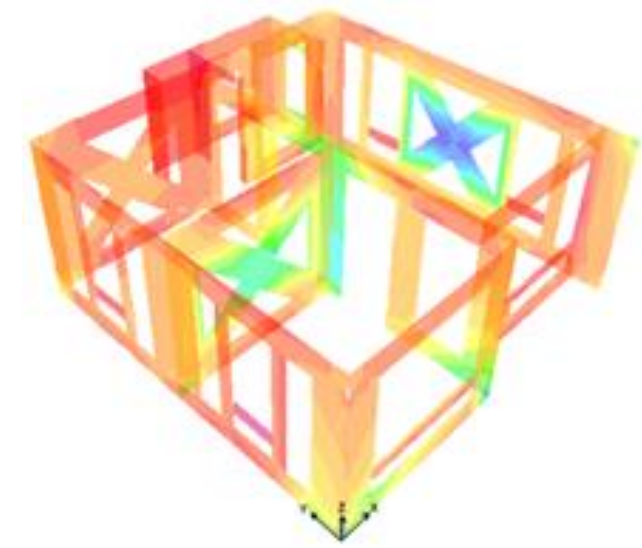

(b)

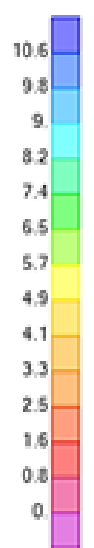

Figure 21. The maximum tensile stress pattern of outer ferrocement layers (unit in $\mathrm{kgf} / \mathrm{cm}^{2}$ ) due to Palu earthquake (a) and Padang earthquake (b) 


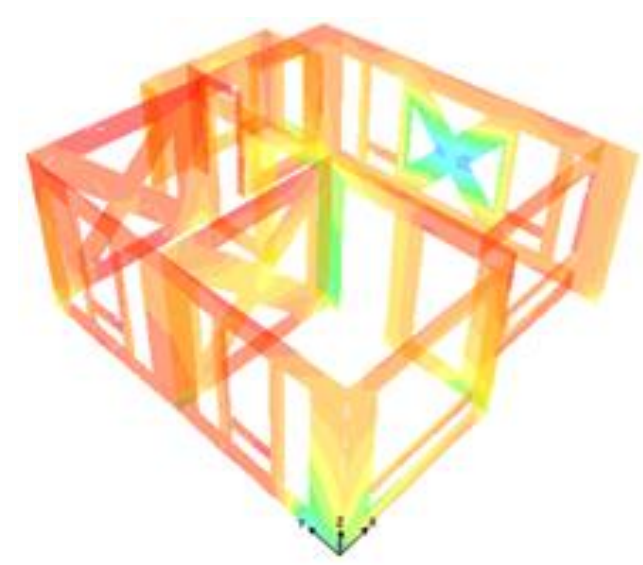

(a)

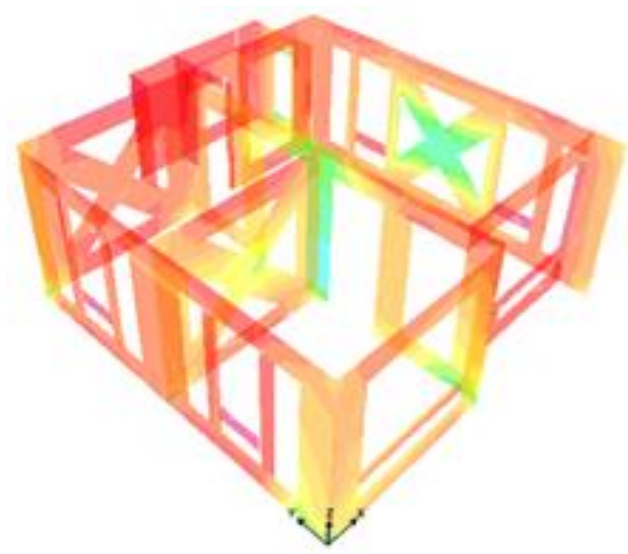

(b)

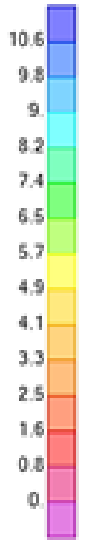

Figure 22. The maximum tensile stress pattern of inner ferrocement layers (unit in $\mathrm{kgf} / \mathrm{cm} 2$ ) due to (a) Palu earthquake and (b) Padang earthquake

\section{Conclusions}

1) Gradual strengthening with ferrocement bandaging significantly improves the earthquake resistance of masonry houses. It is proven by the analysis results using the Padang earthquake, a multiple pulse type, and Palu earthquake, a single pulse type.

2) The gradual strengthening should serve as an educational tool to encourage people to be self-sufficient in building their earthquake-resistant houses to prevent collapse in the future, and people should not depend on government funding to strengthen their houses.

4) It is recommended to strengthen masonry houses by bandaging with ferrocement layers up to stage 3 ; if available, FRC and TRC layers can be used. However, gradual retrofitting can be applied immediately due to limited funding, and all steps shall be completed within one year. Therefore, the masonry houses become earthquake resistant.

\section{Acknowledgment}

The authors would like to thank Prof. Dr. Ir. Masyhur Irsyam, M.S.E., provided the Palu earthquake digitized records September 2018 by Andhika Sahadewa, S.T., M.S.E, Ph.D. Rusnardi Rahmat Putra, S.T., M.T., Ph.D. for providing the West Sumatra earthquake record on September 30th, 2009, and CSI Indonesia for allowing the use of its license of SAP2000 V.23 for the analysis of this paper. 


\section{References}

1. Boen T., Belajar dari Kerusakan Akibat Gempa Bumi: Bangunan Tembokan Nir-Rekayasa di Indonesia, Yogyakarta: Gadjah Mada University Press, 2016.

2. Bandung, Center for Disaster Mitigation Institute Technology, "Data Collection on Non-Engineered Construction in Developing Countries (Indonesia)," National Graduate Institute for Policy Studies (GRIPS), Bandung, 2011.

3. Buana, JICA-PT Aneka Asia, "Final Report Awareness and so on (CS-11011)," Japan International Cooperation Agency (JICA), Jakarta, 2012.

4. Boen T., "Reconstruction in Indonesia Post-2004 Tsunami: Lessons Learnt," Springer-Verlag Berlin Heidelberg, 2014.

5. Boen T., "Indonesian Earthquake Problem," in International Conference on Earthquake Engineering and Disaster Mitigation, 2008.

6. Boen T., "Indonesian Earthquake Problems 2018 and Needed Improvements," in International Conference on Disaster Management, Padang, 2018.

7. Boen T., "Lessons Learned from the Reconstruction of Houses in Aceh Post the December 26th, 2004 Tsunami Catastrophe," 2004.

8. N. K, "Planning Structural Upgrading," Delft, 1992.

9. Boen T., "Building a Safer Aceh, Reconstruction of Houses, One Year After The December 26th, 2004 Tsunami," in 40th Anniversary of Trisakti University, "Answering the Challenges in Today's Civil Engineering," Jakarta, 2006.

10. Boen T., "Reconstruction of Houses in Aceh, Twenty Months After The Tsunami of December 26th, 2004," 2004.

11. Boen T., Priyono J., Reconstruction of Houses in Aceh Post the December 26th, 2004 Tsunami Catastrophe, Six Years After.

12. Kompas, “Gramedia Digital,” Kompas Gramedia, 29 September 2021. [Online]. Available: https://ebooks.gramedia.com/newspapers/kompas/29-sep-2021. [Accessed September 29th, 2021].

13. Boen T., Imai H., Lenny, Suryanto S. E., "Masonry Buildings Strengthened with Textile Fiber Composite (TRC) Layers and Fiber Reinforced Cementitious (FRC) Layers," in International Conference on Disaster Mitigation and Management (ICDMM), to be published, Padang, 2021. 
14. Boen T., Imai H., Ismail F. A., Hanazato T., and Lenny, "Brief Report of Shaking Table Test on Masonry Building," Journal of Disaster Research Vol.10 No.3, 2015, Japan, 2014.

15. Boen T., "Constructing Earthquake Resistant Masonry Houses - Bandaged using Ferrocement Layers," March 1st, 2015. [Online]. Available: https://teddyboen.com/. [Accessed 2409 2021].

16. Standar Nasional Indonesia (SNI) 7973-2013, "Spesifikasi desain untuk konstruksi kayu," Badan Standar Nasional (BSN), Indonesia, 2013.

17. Irsyam M., and Sahadewa A., "Palu, Central Sulawesi Earthquake Record," Bandung Institute of Technology, Bandung, 2018.

18. Rusnardi R. P., “West Sumatra Earthquake Record,” Universitas Negeri Padang, Padang, 2009. 